\title{
Nonobligate Role of Early or Sustained Expression of Immediate- Early Gene Proteins c-Fos, c-Jun, and Zif/268 in Hippocampal Mossy Fiber Sprouting
}

\author{
Walter K. Nahm and Jeffrey L. Noebels \\ Developmental Neurogenetics Laboratory, Department of Neurology, and Division of Neuroscience, Baylor College of \\ Medicine, Houston, Texas 77030
}

Axon sprouting in dentate granule cells is an important model of structural plasticity in the hippocampus. Although the process can be triggered by deafferentation, intense activation of glutamate receptors, and other convulsant stimuli, the specific molecular steps required to initiate and sustain mossy fiber (MF) reorganization are unknown. The cellular immediate early genes (IEGs) c-fos, c-jun, and zif/268 are major candidates for the initial steps of this plasticity, because they encode transcription factors that may trigger cascades of activitydependent neuronal gene expression and are strongly induced in all experimental models of MF sprouting. The mutant mouse stargazer offers an important opportunity to test the specific role of IEGs, because it displays generalized nonconvulsive epilepsy and intense MF sprouting in the absence of regional cell injury. Here we report that stargazer mice show no detectable elevations in c-Fos, c-Jun, or Zif/268 immediate early gene proteins (IEGPS) before or during MF growth. Experimental results in stargazer, including (1) a strong IEGP response to kainate-induced convulsive seizures, (2) no IEGP response after prolongation of spike-wave synchronization, (3) no IEGP increase at the developmental onset of seizures or after prolonged seizure suppression, and (4) unaltered levels of the intracellular $\mathrm{Ca}^{2+}$-buffering proteins calbindin- $\mathrm{D}_{28 \mathrm{k}}$ or parvalbumin, exclude the possibility that absence of an IEGP response in stargazer is either gene-linked or suppressed by known refractory mechanisms. These data demonstrate that increased levels of these IEGPs are not an obligatory step in MF-reactive sprouting and differentiate the early downstream molecular cascades of two major seizure types.

Key words: spike-wave epilepsy; transcription factor; axon sprouting; hippocampus; plasticity; cell death
Axonal sprouting and neosynaptogenesis play functional roles in reorganization and repair throughout the mammalian CNS (Cotman et al., 1981; West and Dewey, 1984; Fitzgerald et al., 1990; Darian-Smith and Gilbert, 1994). These processes are associated with complex patterns of activity and injury-dependent gene expression (Gall and Isackson, 1989; Nedivi et al., 1993; Chen et al., 1995; Konopka et al., 1995). The products of these plasticityrelated genes are thought to be responsible for axonal outgrowth, guidance, and establishment of functional synapses. It is widely proposed that immediate early genes (IEGs) encode the initial transcription factors that modulate the expression of these genes (Sheng and Greenberg, 1990, Morgan and Curran, 1991a).

In the dentate gyrus, a well defined pattern of axon sprouting from the granule cell-mossy fiber (MF) system into the inner molecular layer has been found in several models of hypersynchronous activation, including kainic acid (KA) (Tauck and Nadler, 1985), kindling (Cavazos et al., 1991), and pentylenetetrazole (PTZ) (Golarai et al., 1992). Several lines of evidence link IEG induction with this process. Elevation of the mRNAs for $c$-fos, $c$-jun, and zif/268 precedes that of other genes associated with MF sprouting. Recurrent sprouting and IEG induction occur in the same cells, with sprouting occurring several days after the induction of IEGs (Morgan and Curran, 1991b). Both

\footnotetext{
Received July 15, 1998; revised Aug. 26, 1998; accepted Sept. 1, 1998.

This work was supported by National Institutes of Health Grant NS29709 and The Blue Bird Circle Foundation for Pediatric Neurology.

Correspondence should be addressed to Dr. Jeffrey L. Noebels, Department of Neurology, Baylor College of Medicine, One Baylor Plaza, Houston, TX 77030

Copyright (C) 1998 Society for Neuroscience $0270-6474 / 98 / 189245-11 \$ 05.00 / 0$
}

$c$-fos expression and MF-sprouting induction have roughly equivalent dose thresholds for PTZ (Dragunow and Robertson, 1987; Morgan et al., 1987). Drugs that prevent kindling and the induction of $c$-fos block MF sprouting (Kiessling and Gass, 1993). Finally, kindling-induced sprouting is impaired in $c$-fos null mutant mice (Watanabe et al., 1996).

Although the process of MF synaptic reorganization is highly correlated with IEG induction, all MF sprouting models described so far are also associated with regional cellular injury, death, synaptic loss, and gliosis (Cavazos and Sutula, 1990; Houser et al., 1990; Wallace and Fredens, 1992). Because IEG induction is closely associated with cell death (Curran and Morgan, 1995; Kasof et al., 1995), the presence of seizure-related injury obscures the actual stimulus for IEG expression, and it remains unclear whether immediate early gene proteins (IEGPs) are necessary or sufficient for aberrant axonal growth.

An opportunity to dissociate the role of IEGPs in MF sprouting from seizure-related damage arose with the neurological mutant stargazer. This mutant exhibits a stereotyped pattern of brief $(1-10 \mathrm{sec})$ generalized six per second spike-wave (SW) discharges in the neocortex, hippocampus, and thalamus (Noebels et al., 1990). These hypersynchronous SW discharges occur frequently (one or two per minute) and precede by several weeks the progressive appearance of MF axon sprouting. No evidence of hippocampal cell death, gliosis, or cellular injury at the onset of sprouting has been found (Qiao and Noebels, 1993; Chafetz et al., 1995). To determine whether the hippocampal IEGP expression pattern is coupled to MF sprouting despite the absence of cellular injury, we compared the neuronal staining patterns of polyclonal 
antibodies to c-Fos, c-Jun, and Zif/268 in stargazer with those expressed in a sprouting model induced by KA. We also examined relative IEGP activation thresholds, the potential involvement of refractory mechanisms inhibiting IEGP induction, and the role of two $\mathrm{Ca}^{2+}$-binding proteins, calbindin- $\mathrm{D}_{28 \mathrm{k}}$ and parvalbumin.

\section{MATERIALS AND METHODS}

Mice. Homozygous stargazer $(\mathrm{C} 3 \mathrm{~B} 6 \mathrm{Fe}+$ stg/stg) and wild-type $(\mathrm{C} 57 \mathrm{Bl} / 6 \mathrm{~J}$ $+/+$ ) mice were obtained from breeding colonies of The Jackson Laboratory (Bar Harbor, ME) and Baylor College of Medicine. Animals were housed under a $12 \mathrm{hr}$ light/dark cycle with ad libitum access to food and water. Unless otherwise noted, mice used in experiments were adults ranging from 2-6 months old.

Electrocorticographic recordings. Mice were anesthetized with Avertin ( $1.25 \%$ tribromoethanol/amyl alcohol) by intraperitoneal injection $(0.02$ $\mathrm{ml} / \mathrm{gm}$ body weight). Teflon-coated silver wire electrodes $(0.005$ inch diameter) soldered to a microminiature connector were implanted through burr holes ( 0.1 inch diameter) of the skull into the subdural space over the frontal and occipital cortices (Noebels et al., 1990). The microminiature connector was affixed permanently to the midline surface of the skull with cyanoacrylate glue and dental cement. All experiments and electrocorticographic (ECoG) recordings commenced 1 week after surgery. ECoG activity in alert and unrestrained mice was recorded using a Grass model 6 electroencephalograph.

Convulsive seizure induction. Wild-type and stg/stg mice were injected with KA (30 mg/kg, i.p.), a convulsant known to induce seizures that precede MF synaptic reorganization in the hippocampus (Tauck and Nadler, 1985). By the first 20-30 min after injection, both genotypes exhibited typical class V limbic seizures (Racine, 1972) consisting of episodes of motionless behavior, followed by myoclonic facial movements, forepaw tremor, rearing, and falling with loss of postural balance. In both $s t g / s t g$ and $+/+$, status epilepticus occurred $1.5-2 \mathrm{hr}$ after injection, followed by generalized tonic-clonic convulsions. Stargazer mice displayed on average more severe seizures and a quicker onset to seizures than did wild-type mice. Mice were killed for immunohistochemistry (IHC) $2 \mathrm{hr}$ after KA injection to assess regional c-Fos, c-Jun, and $\mathrm{Zif} / 268$ expression in the brain.

(土)-3-(2-carboxypiperazin-4-yl)-propyl-1-phosphonic acid treatment. $\mathrm{Pi}$ lot experiments revealed that $\mathrm{stg} / \mathrm{stg}$ mice injected intraperitoneally with $40 \mu \mathrm{M} / \mathrm{kg}$ of the competitive NMDA receptor antagonist $( \pm)-3-(2-$ carboxypiperazin-4-yl)-propyl-1-phosphonic acid (CPP) displayed prolonged episodes of continuous SW ECoG activity lasting $60 \mathrm{~min}$ or longer (Nahm and Noebels, 1995). The proepileptic effect of this treatment, which had no discernable effect on ECoG activity in $+/+$ mice and blocked SW activity in another SW-MF sprouting model, tottering (Stanfield, 1989), was used to experimentally enhance SW synchronization in $s t g / s t g$. One hour of ECoG recordings was first obtained in stg/stg mutants to quantify baseline SW activity. Within thirty min of CPP injection, near-continuous SW synchronization appeared (individual discharges increased 10- to 100-fold in duration). These animals were killed $2 \mathrm{hr}$ after the onset of prolonged SW activity to examine regional IEGP expression in the brain.

Ethosuximide treatment. To produce a complete blockade of SW seizure activity for a period of $30 \mathrm{hr}$, an stg/stg mouse was injected intraperitoneally with $200 \mathrm{mg} / \mathrm{kg}$ of ethosuximide (ETX) (Heller et al., 1983; Marescaux et al., 1992) approximately every 2 hr. Continuous ECoG monitoring was performed to determine dose intervals and to verify the absence of SW discharges. At the end of the seizure-free period, ETX injections were discontinued, and the mouse was killed for IHC $2 \mathrm{hr}$ after the spontaneous SW seizure activity resumed.

Immunohistochemistry. Mice were deeply anesthetized with Avertin $(0.02 \mathrm{ml} / \mathrm{gm}$, i.p. $)$ and perfused transcardially with $0.1 \mathrm{M}$ phosphate buffer (PB), $\mathrm{pH} 7.4$, followed by $4 \%$ paraformaldehyde in $0.1 \mathrm{M}$ PB. The brains were removed, post-fixed for $24 \mathrm{hr}$, and immersed in $30 \%$ sucrose in 0.1 M PB for $5 \mathrm{~d}$. Horizontal sections ( $40 \mu \mathrm{m}$ thickness) through the whole brain were cut on a freezing microtome and pretreated in $0.03 \% \mathrm{H}_{2} \mathrm{O}_{2}$ in absolute methanol. Tissue sections were then immersed in $2 \%$ bovine serum albumin (BSA) in $0.1 \mathrm{M}$ PBS for $3 \mathrm{hr}$ and processed using the free-floating method with thorough rinsing between steps. Sections were incubated at $4^{\circ} \mathrm{C}$ with either: (1) 1:400 c-Fos sheep polyclonal antibody (Cambridge Technologies, Watertown, MA) in $0.1 \mathrm{M}$ PBS with $1 \%$ BSA for $24 \mathrm{hr}$; (2) 1:400 c-Jun rabbit polyclonal antibody (Oncogene Science) in $0.1 \mathrm{M}$ PBS with $1 \% \mathrm{BSA}$ for $24 \mathrm{hr}$; (3) $1: 300 \mathrm{Zif} / 268 \mathrm{rabbit}$ polyclonal antibody (Santa Cruz Biotechnology, Santa Cruz, CA) in 0.1 м PBS with $1 \%$ BSA for $48 \mathrm{hr}$; (4) 1:200 calbindin- $\mathrm{D}_{28 \mathrm{k}}$ mouse monoclonal antibody (Sigma, St. Louis, MO) in 0.1 M PBS with 1\% BSA for $24 \mathrm{hr}$; or (5) 1:400 parvalbumin mouse monoclonal antibody (Sigma) in $0.1 \mathrm{M}$ PBS with $1 \%$ BSA for $24 \mathrm{hr}$. Sections were then incubated for $60 \mathrm{~min}$ at room temperature with the appropriate biotinylated secondary antibody (Jackson ImmunoResearch, West Grove, PA) at 1:100, and followed by an incubation in an avidin-biotin-horseradish peroxidase (HRP) complex (ABC kit; Vector Laboratories, Burlingame, CA) (Hsu et al., 1981). The bound peroxidase was localized by incubating sections in $0.1 \% 3,3^{\prime}$ diaminobenzidine (DAB) and $0.025 \% \mathrm{H}_{2} \mathrm{O}_{2}$ at room temperature for 5-10 min, which generated the visible substrate. Sections incubated without the primary antibody served as controls. All the sections were examined and photomicrographed using standard light microscopy (Leitz, Orthoplan 2 and Vario Orthomat 2). Because variation occurs along the septal-temporal gradient, all levels of the hippocampal formation were analyzed in all experiments. A $0-4^{+}$rating scale was used to quantify visible substrate staining intensity in cell nuclei using standard light microscopy. All slides were scored by a single observer to ensure consistency. A score of 0 was assigned when staining was completely absent. A score of $1^{+}$was assigned to minimal basal level staining, $2^{+}$for moderate staining, and $3^{+}$for high staining. The greatest score of $4^{+}$was only assigned to maximal nuclear staining patterns usually observed in the dentate gyrus under KA administration.

\section{RESULTS}

\section{Absence of elevated IEGP expression in stg/stg hippocampus}

Regional expression patterns of c-Fos, c-Jun, and Zif/268 were assayed in 12 adult mutant mice (stg/stg) and compared with those of 12 age-matched wild-type control $(+/+)$ mice. All stg/stg and $+/+$ mice displayed a consistent lack of nuclear c-Fos staining in the dentate granule cells and other neurons of the hippocampus (Fig. 1). In both genotypes, minimal basal levels of specific nuclear c-Fos staining were found sporadically in the neocortex, thalamus, and septum. Specific staining throughout the remainder of the mutant brain was negligible, and no significant genotypic differences in regional c-Fos nuclear staining was identified (Table 1).

In contrast to SW seizures found in the mutant, limbic seizures induced by KA produced clear increases in nuclear c-Fos expression in six assayed adult wild-type $(+/+)$ mice. c-Fos staining in the KA model (+/+-KA) was most intense in the dentate granule cells, and elevated in pyramidal neurons of all the hippocampal subregions (CA1, CA2, and CA3) (Fig. 1). c-Fos expression was also diff usely elevated in neuronal nuclei of the entorhinal cortex, thalamus, basal ganglia, septum, and most layers of the neocortex (Table 1).

The pattern of polyclonal antibody staining to c-Jun revealed moderate immunoreactivity in all hippocampal subregions of both stg/stg and +/+ brains (Fig. 1). As in the c-Fos experiments, both genotypes displayed light or negligible c-Jun staining in the neocortex and thalamus, and no consistent differences in the density of neuronal staining for c-Jun were observed between the two genotypes. KA-induced seizures produced large increases in c-Jun staining in the wild-type dentate gyrus and CA1 pyramidal neurons and elevated to a lesser degree c-Jun staining in the hippocampal CA3 subregion. However, no consistent c-Jun staining above basal levels was found after a KA seizure in any other brain area (Table 1$)$.

Both $s t g / s t g$ and $+/+$ displayed identical patterns of Zif/268 antibody staining in the forebrain. In the septal hippocampus of both genotypes, there was light staining in the dentate gyrus and CA1 pyramidal cells. The temporal hippocampus, however, was devoid of Zif/268 staining in both genotypes. In stg/stg there was moderate Zif/268 staining in neocortex, entorhinal cortex, and 
stg/stg $\quad+/+\quad+/+-K A$

++++ Sprouting

- Sprouting

++++ Sprouting
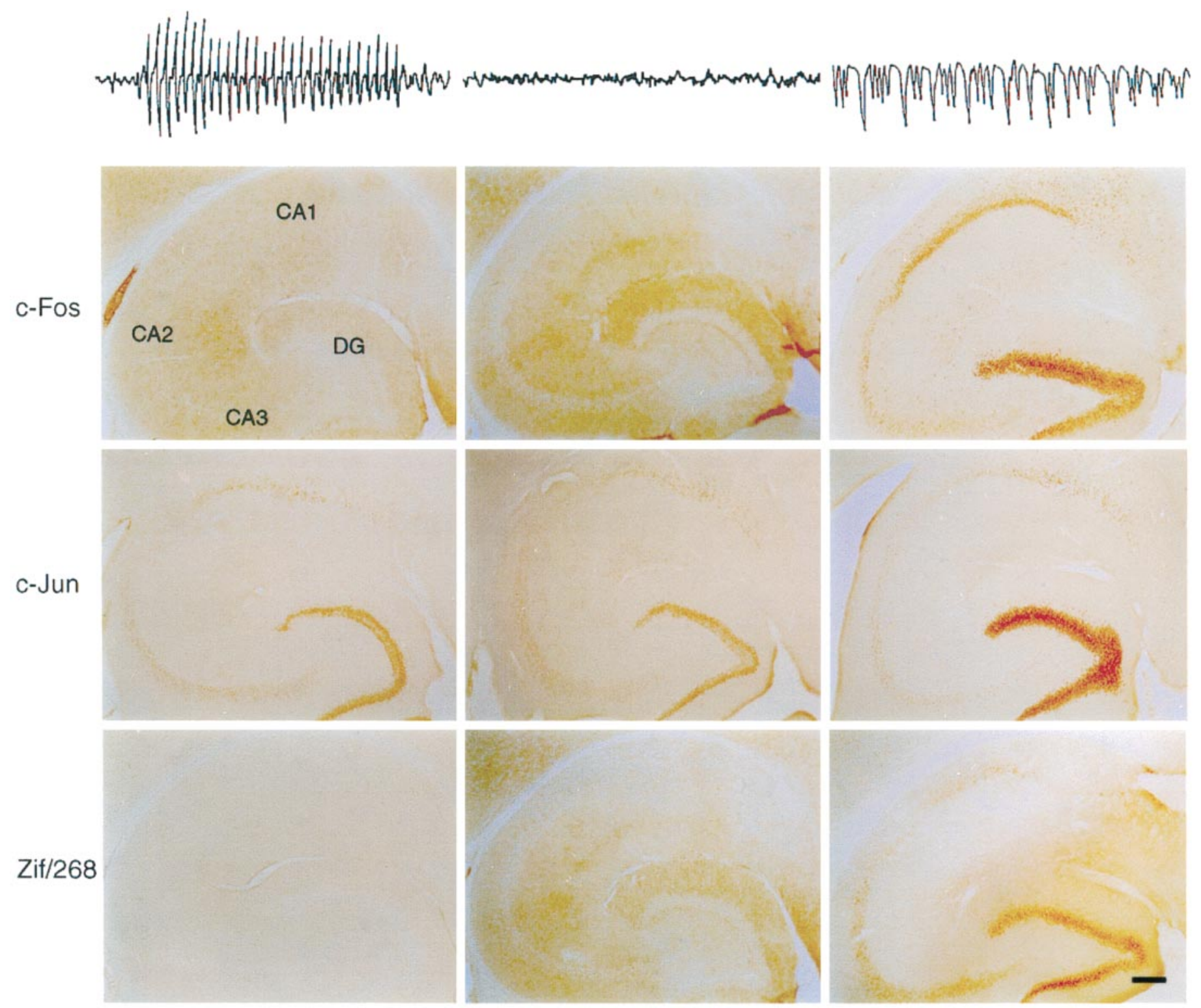

Figure 1. Stargazer mutants show no resting elevations in c-Fos, c-Jun, or Zif/268. Comparison of sprouting pattern, electrocortical activity, and IEG protein expression patterns in the hippocampus of adult $s t g / s t g,+/+$, and $+/+-$ KA mice $(2 \mathrm{hr}$ after kainic acid-induced limbic seizures). Top, Stargazer and +/+-KA mice display strong mossy fiber sprouting in the inner molecular layer of dentate gyrus. Representative 8 sec samples of ECoG recordings display spontaneous six or seven per second spike-wave discharges in the mutant that are not present in the wild-type control, whereas the ECoG recordings during kainic acid convulsive seizures show continuous discharges associated with tonic neuronal depolarizations. Bottom, In temporal hippocampus, stg/stg mice are devoid of c-Fos and Zif/268 staining in a pattern identical to $+/+$ mice and show moderate antibody staining to c-Jun in dentate granule cells and the pyramidal cell layers. Wild-type mice with KA-induced seizures display a strong c-Fos, c-Jun, and Zif/268 response that is greatest in the DG. Moderate elevations of c-Fos and Zif/268 and lesser elevations of c-Jun were seen in CA1, CA2, and CA3 pyramidal regions. Scale bar, $100 \mu \mathrm{m}$.

basal ganglia; this pattern of staining was identical to that found in $+/+$ mice. The pattern of $\mathrm{Zif} / 268$ expression in $+/+$ mice treated with KA showed extreme elevations in dentate granule cells and CA1 pyramidal neurons (Fig. 1; Table 1). Zif/268 expression was slightly elevated in CA2 but conspicuously absent in CA3 neurons. KA-induced seizures also greatly raised the number of $\mathrm{Zif} / 268$-stained neurons in the neocortex and entorhinal cortex, and diffuse, moderate elevations of Zif/268 staining 


\begin{tabular}{|c|c|c|c|}
\hline Region & $\begin{array}{l}\text { stg/stg } \\
(n=12)\end{array}$ & $\begin{array}{l}+/+ \\
(n=12)\end{array}$ & $\begin{array}{l}+/+ \text {-kainic acid } \\
(n=6)\end{array}$ \\
\hline \multicolumn{4}{|l|}{ c-Fos intensity } \\
\hline Dentate gyrus & 0 & 0 & ++++ \\
\hline CA1 & 0 & 0 & ++++ \\
\hline CA2 & 0 & 0 & +++ \\
\hline $\mathrm{CA} 3$ & 0 & 0 & +++ \\
\hline Neocortex & 0 & 0 & ++ \\
\hline Thalamus & 0 & 0 & ++ \\
\hline Entorhinal cortex & 0 & 0 & ++ \\
\hline Septum & 0 & 0 & +++ \\
\hline \multicolumn{4}{|l|}{ c-Jun intensity } \\
\hline Dentate gyrus & + & + & +++ \\
\hline CA1 & + & + & +++ \\
\hline CA2 & + & + & +++ \\
\hline CA3 & 0 & 0 & + \\
\hline Neocortex & 0 & 0 & + \\
\hline Thalamus & 0 & 0 & 0 \\
\hline Entorhinal cortex & 0 & 0 & 0 \\
\hline Septum & 0 & 0 & 0 \\
\hline \multicolumn{4}{|l|}{ Zif/268 intensity } \\
\hline Dentate gyrus & 0 & 0 & ++++ \\
\hline CA1 & 0 & 0 & ++ \\
\hline CA2 & 0 & 0 & 0 \\
\hline CA3 & 0 & 0 & 0 \\
\hline Neocortex & + & + & ++ \\
\hline Thalamus & 0 & 0 & + \\
\hline Entorhinal cortex & 0 & 0 & +++ \\
\hline Septum & 0 & 0 & + \\
\hline
\end{tabular}

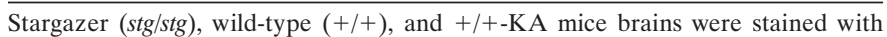
polyclonal antibodies for c-Fos, c-Jun, and Zif/268 and evaluated by light microscopy. Each value represents the mean intensity of IEGP staining. The values were determined by a $0-4+$ rating scale in increments of one. A score of 0 was assigned when no staining was present. Minimal basal levels of staining were assigned a score of $1+$. Maximal nuclear staining was assigned a score of $4+$. No variability was found for scores of 0 and $4+$. The intervening scores $(1+-3+)$ varied by less than one unit among mice of the same genotype.

were found in the thalamus, basal ganglia, and septum (Table 1). These experiments demonstrate the presence of a striking difference in hippocampal IEGP expression between two types of hypersynchronous seizure activity that induce similar patterns of MF sprouting (spike-wave seizures in stg/stg and convulsive seizures in +/+-KA).

To ensure that the absence of an IEGP response to SW discharge activity was not specific for the stargazer mutation, we analyzed an adult tottering mouse, a mutation on a different genetic background that also shows SW discharge and sprouting activity (Stanfield, 1989). No abnormal c-Fos staining was observed, and c-Fos elevation was not seen in the neocortex of an inbred rat strain with SW discharges (Willoughby et al., 1993), suggesting that the SW pattern itself may be ineffective in inducing IEGP activity regardless of genetic background.

\section{IEGP induction patterns in stargazer brain}

The absence of IEGP induction above basal levels in stg/stg hippocampus, thalamus, and neocortex was unexpected, considering the frequent bursts of SW synchronization generated in these areas and the strong increase in IEGP levels that follow neuronal activation during synchronous discharges in other sei- zure models. This finding raised the possibility that the SW pattern might synchronize neurons by activating synaptic networks below the depolarization threshold required to initiate a measurable IEGP response, suggesting that the intensity of this pattern of abnormal synchronization differed significantly from those found in other experimental epilepsy models. Other factors, however, could potentially mask the induction of a detectable c-Fos, c-Jun, and Zif/268 response in the mutant and mitigate this conclusion, namely: (1) a gene-linked defect in one or more steps of the stimulus transduction pathway of IEGP expression in $\mathrm{stg} / \mathrm{stg}$ neurons; (2) the brevity $(1-10 \mathrm{sec})$ of individual SW episodes relative to seizures in other experimental models; (3) short-term inactivation of IEGP expression in cells engaged in SW bursting; (4) longer-term cellular refractory mechanisms for sustained IEGP expression activated by chronic SW stimulation; and (5) increased buffering capacity of intracellular free $\mathrm{Ca}^{2+}$ in $s t g / s t g$ neurons. These possibilities were evaluated in a series of control experiments (Figs. 2-6).

\section{Robust stimulus-induced IEGP expression in $\mathrm{stg} / \mathrm{stg}$ neurons}

To test whether the lack of IEGP induction in stg/stg neurons during SW activity might be caused by a gene-linked neuronal defect in the intervening steps of the transynaptic induction pathway, six stg/stg mice were injected with KA $30 \mathrm{mg} / \mathrm{kg}$ intraperitoneally (stg/stg-KA), monitored for ECoG seizure activity for $2 \mathrm{hr}$, and killed for IHC (Fig. 2A). Within the first 15 min after injection, mutant mice exhibited typical class I-II seizure activity. This activity was soon followed by class V limbic seizures and generalized tonic-clonic seizures. In a similar manner to wildtype mice, the seizures induced by KA produced clear increases in nuclear expression of the IEGPs, c-Fos, c-Jun, and Zif/268, in $s t g / s t g$. In the $s t g / s t g$ hippocampal formation, KA produced increases in expression of c-Fos in nuclei of DG, CA1, CA2, and CA3 neurons (Fig. 2B). In addition, strong c-Fos staining was observed in neocortex, entorhinal cortex, thalamus, basal ganglia, and septum. Clear increases in c-Jun expression were found in the $\mathrm{DG}$, and smaller elevations were found in CA1, CA2, and CA3 regions (Fig. 2B). No c-Jun staining above basal levels was found in any other brain area. KA-induced seizures produced a pattern of intense Zif/268 elevation in DG neurons and moderate elevations of Zif/268 in the hippocampal pyramidal layer subregions (CA1, CA2, and CA3) in stg/stg (Fig. 2B). The mutant neocortex and entorhinal cortex also displayed a strong elevation of $\mathrm{Zif} / 268$, whereas the thalamus, basal ganglia, and septum showed mild Zif/268 increases. These data show that stg/stg neurons are capable of seizure-induced IEGP expression. More precisely, these data demonstrate that the specific population of dentate granule cells in the temporal hippocampus of $\mathrm{stg} / \mathrm{stg}$ that are involved in recurrent MF sprouting can display a robust induction of c-Fos, c-Jun, and Zif/268.

\section{Prolongation of SW activity does not increase IEGP expression} Preliminary pharmacological survey revealed that the NMDA receptor glutamate-binding site antagonist CPP paradoxically increases SW seizure activity in stargazer, in contrast to its antiepileptic effects in other epilepsy models. To test the possibility that spontaneous SW seizures in stg/stg were simply too brief (1-10 sec) or infrequent (one or two per minute) to elevate IEGPs over basal levels, IHC to c-Fos, c-Jun, and Zif/268 was performed on seven $s t g / s t g$ mice injected $(40 \mu \mathrm{g} / \mathrm{kg}$, i.p.) with CPP (stg/stg-CPP). Within $30 \mathrm{~min}$ of treatment, the ECoG of these mice converted from a pattern of brief intermittent SW dis- 


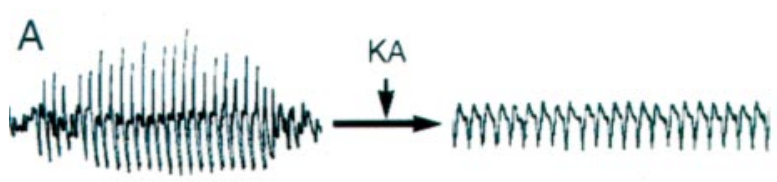

B
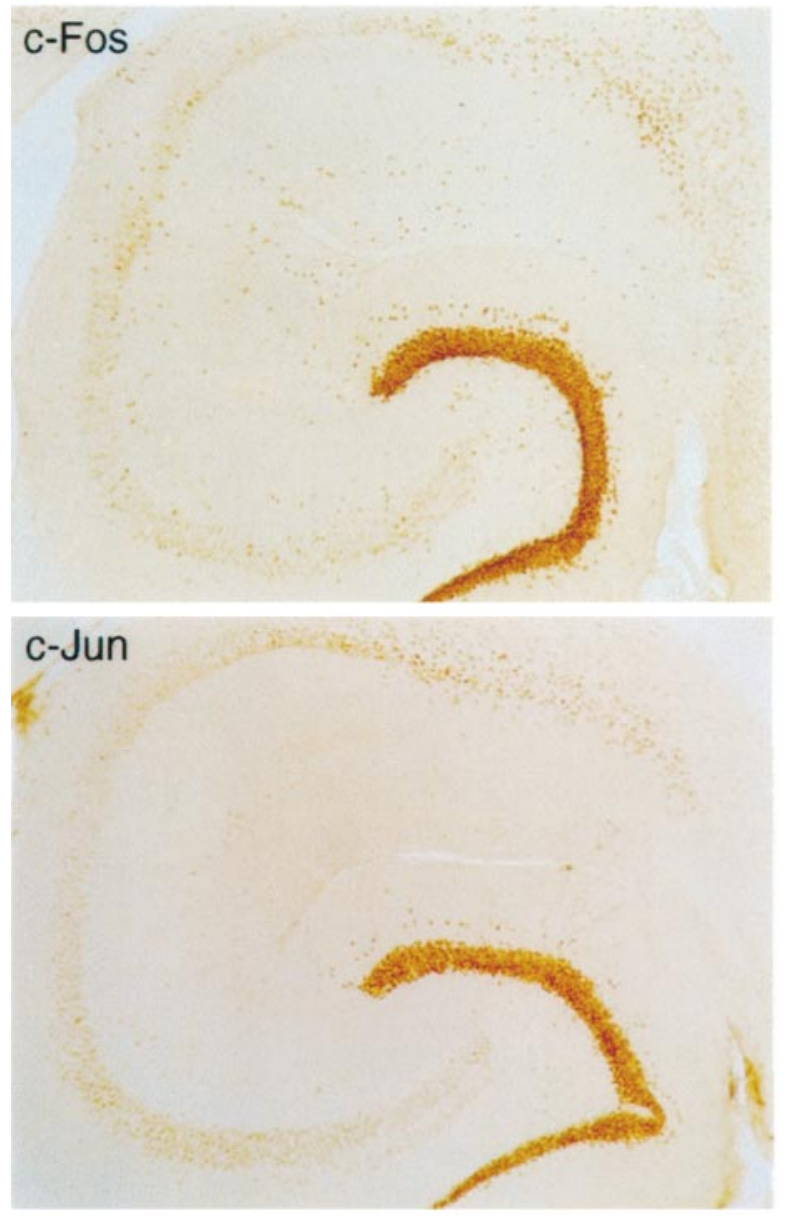

\section{Zif/268}

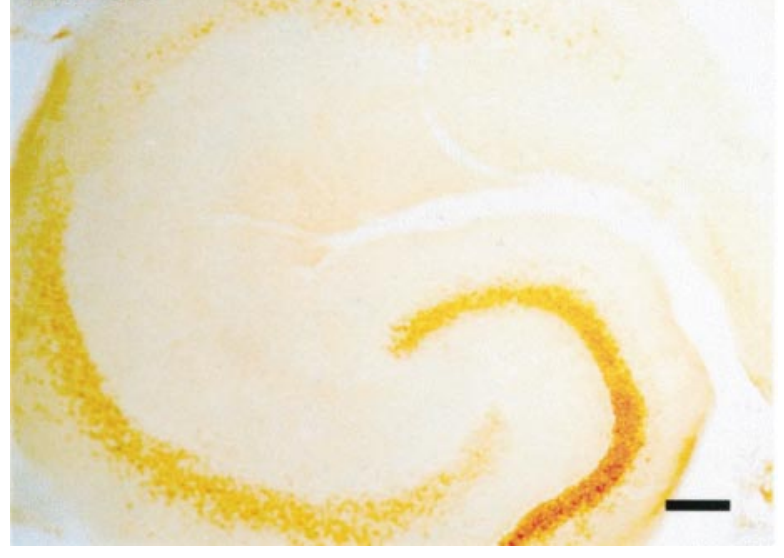

Figure 2. Stargazer mice demonstrate a strong IEGP response after KA-induced seizures. $A$, ECoG recordings demonstrate that inherited spike-wave seizures were converted to tonic discharges after intraperitoneal administration of $30 \mathrm{mg} / \mathrm{kg}$ of KA. $B$, IEGP expression patterns in $s t g / s t g$ examined $2 \mathrm{hr}$ after KA treatment reveal strong inductions of c-Fos and Zif/268 in DG, CA1, CA2, and CA3. Strong c-Jun expression was found in the DG, and lesser elevations of c-Jun were detected in the pyramidal layers. Scale bar, $100 \mu \mathrm{m}$.
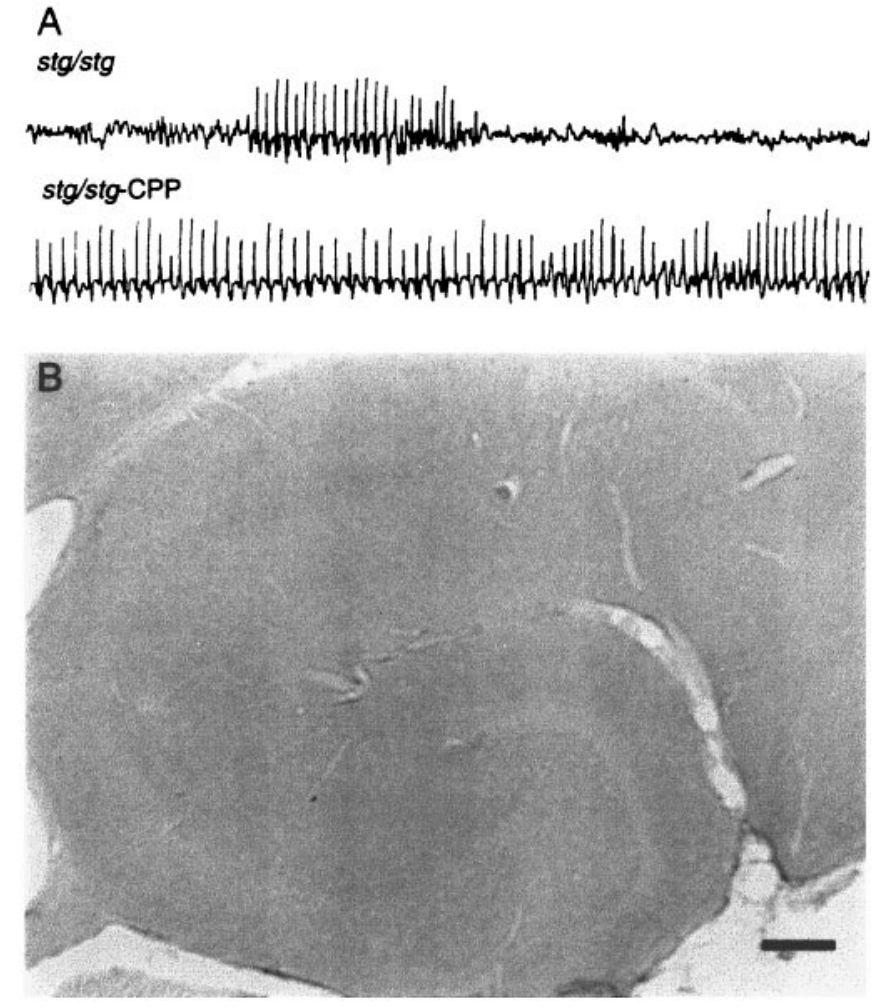

Figure 3. Prolongation of SW activity with CPP does not induce c-Fos expression pattern in $s t g / s t g . A$, ECoG recordings in a stg/stg mutant demonstrate the conversion of spontaneous SW discharges to prolonged status-like SW activity after injection of CPP (40 $\mu \mathrm{M} / \mathrm{kg}$, i.p.). B, After 2 hr of CPP-induced prolonged SW activity, stg/stg hippocampus displays no change in c-Fos expression. c-Jun and $\mathrm{Zif} / 268$ levels were also unchanged (data not shown). Scale bar, $100 \mu \mathrm{m}$.

charges to a nearly continuous (95\% of elapsed time) pattern of typical six per second SW bursting lasting $\sim 2 \mathrm{hr}$ accompanied by behavioral immobility (Fig. $3 A$ ). Although the possibility exists that CPP, an NMDA receptor antagonist, might indirectly block IEGP induction, recent evidence shows that other NMDA antagonists MK-801 (Dragunow and Faull, 1990; Sharp et al., 1990; Hughes et al., 1993) and ketamine (Nakao et al., 1993) allow distinct induction of IEGPs in the CNS, presumably through non-NMDA receptor $\mathrm{Ca}^{2+}$ signaling pathways (Lerea et al., 1992).

Sections from CPP-treated stg/stg mice killed after $2 \mathrm{hr}$ of continuous SW activity showed a pattern of c-Fos, c-Jun, and $\mathrm{Zif} / 268$ staining in the hippocampal formation identical to that seen in untreated stg/stg mice (Fig. 3B). No increases in c-Fos over basal levels were detected throughout all other brain regions examined, and similar results were found with c-Jun and Zif/268 staining patterns. The low levels of hippocampal IEGP expression were identical to the basal levels seen in untreated stg/stg mice (Fig. 1). These data suggest that the brief duration of individual spontaneous SW discharges is not a critical factor in the lack of a sustained IEGP response in the mutant, and that the amount of neuronal depolarization during this pattern of activity remains below the threshold for IEGP induction.

Short-term refractory mechanisms are not responsible for the lack of IEGP induction in stg/stg mice

Seizures induced by an initial dose of the convulsant PTZ are followed by a short (up to $16 \mathrm{hr}$ ) period during which a second 

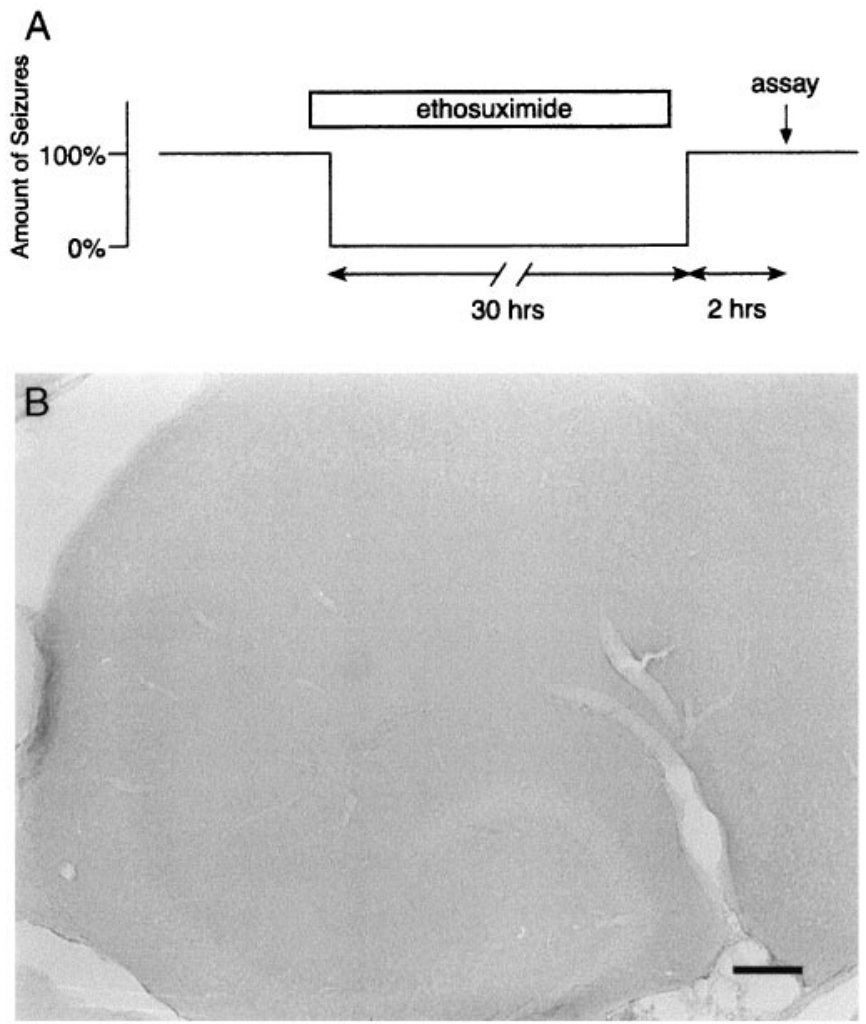

Figure 4. Short-term refractory mechanisms do not account for lack of c-Fos expression in $s t g / s t g$ mice with chronic SW seizures. A, Schematic diagram shows blockade of basal SW discharge activity in a mutant mouse for $30 \mathrm{hr}$ with ethosuximide injections. SW seizures (approximately one per minute) were allowed to resume, and IHC for IEG proteins was performed $2 \mathrm{hr}$ later. $B$, IHC of $s t g / s t g$ hippocampus after seizure suppression treatment shown in $A$ reveals no abnormal induction of c-Fos. c-Jun and Zif/268 patterns were also unchanged (data not shown). Scale bar, $100 \mu \mathrm{m}$.

dose of PTZ is unable to further induce c-fos (Morgan et al., 1987). A desensitization of this type to $c$-fos and zif/268 induction in the brain is also found after acute administration of cocaine (Ennulat et al., 1994). This interval in which IEGs are persistently suppressed even in the presence of an effective stimulus is referred to as a short-term refractory period. To determine whether short-term refractoriness may have contributed to the lack of IEGP response in stg/stg mice, SW seizures were completely blocked for $30 \mathrm{hr}$ with repeated injections of ETX (Fig. $4 A$ ). At the end of this time, ETX administration was discontinued, and seizure activity was allowed to return for $2 \mathrm{hr}$. The stg/stg mouse brain was then examined for IEGP expression. No changes in c-Fos expression in granule cells or other brain regions were found after the ETX treatment in comparison to untreated stg/stg mice (Fig. 4B). Similarly, there were no apparent changes in c-Jun or Zif/268 expression patterns. These data imply that short-term refractory mechanisms do not contribute to the lack of stg/stg IEGP induction during SW seizures.

Postnatal day 17 and $18 \mathrm{stg} / \mathrm{stg}$ mutants do not display IEGP elevations over basal levels

Winston et al. (1990) reported a second, longer lasting ( $>1$ day) refractory period for $c$-fos and $c$-jun mRNA induction after chronic electroconvulsive seizures. Unlike short-term inactivation, this inhibition was maximal after $8-10 \mathrm{~d}$ of daily stimulation
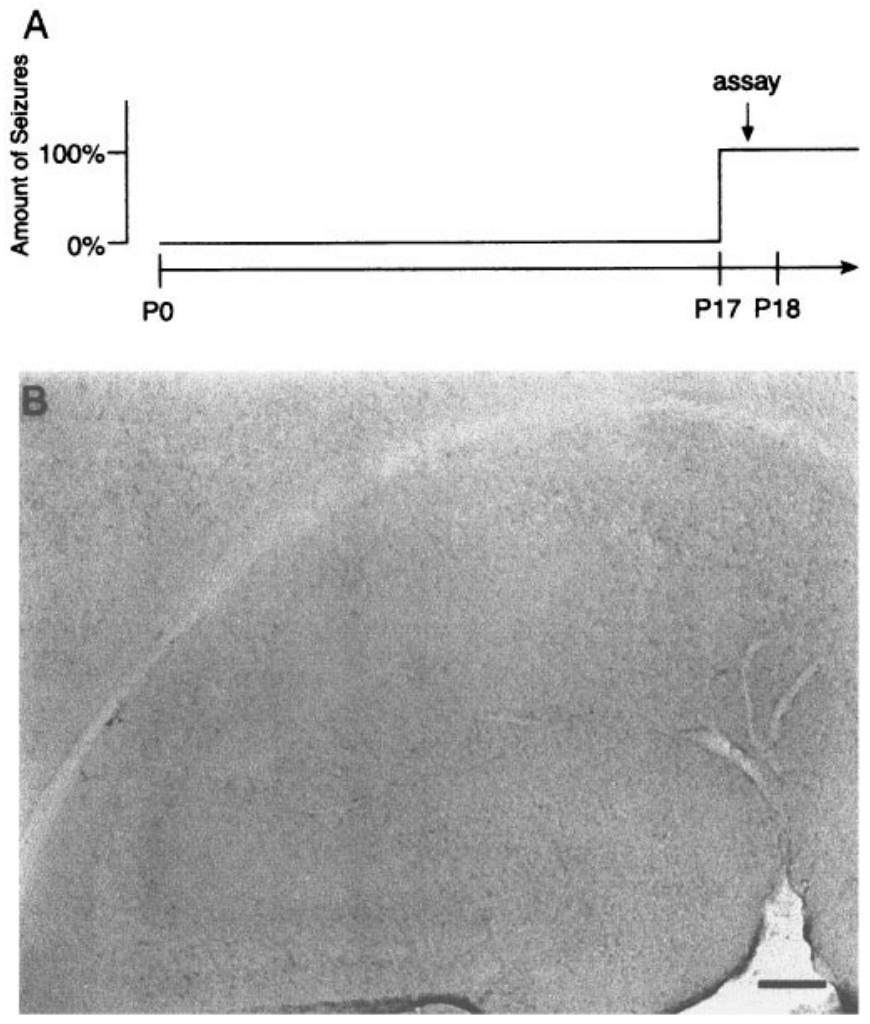

Figure 5. Long-term refractory mechanisms do not account for absence of c-Fos induction in stargazer mice. $A$, Schematic diagram illustrates the experimental time point for IEGP analysis, performed within $1 \mathrm{~d}$ of the developmental onset (P17-P18) of spike-wave seizures in stg/stg mutants. $B$, IHC of P17-P18 stg/stg hippocampus reveals the absence of c-Fos expression after spike-wave seizure onset. No c-Jun or Zif/268 changes in this tissue were seen (data not shown). Scale bar, $100 \mu \mathrm{m}$.

and did not appear to be related to c-Fos autoregulation, because it occurred in the absence of increased c-Fos protein. To test whether similar long-term refractory mechanisms maintained by chronic SW seizures might result in a persistent block of IEGP induction, stg/stg brains were examined within $24 \mathrm{hr}$ of the developmental onset of SW seizures during the third postnatal week, postnatal days 17 and 18 (P17-P18) (Fig. 5A) (Qiao and Noebels, 1993). Because the capacity for $c$-fos induction is already well established at this age (Schreiber et al., 1992; Jensen et al., 1993; Smeyne et al., 1993), the potential for IEGP induction by SW seizure activity in P17-P18 stg/stg mice should not be masked by either short- or long-term IEGP expression refractory mechanisms.

As in the adult, hippocampal sections from P17-P18 stg/stg displayed no evidence of increased c-Fos staining relative to the wild type (Fig. 5B). Similar results were found with c-Jun and Zif/268 antibodies. In other brain regions, the only significant findings among the three IEGP expression patterns were slight elevations in Zif/268 staining present diffusely in neocortex, entorhinal cortex, and basal ganglia in the young mutants compared with the adults.

These data indicate that neither type of refractory mechanism is likely to account for the lack of c-Fos, c-Jun, and Zif/268 induction in stargazer mutants. The previous finding that KAinduced seizures in adult $\mathrm{stg} / \mathrm{stg}$ caused marked c-Fos, c-Jun, and Zif/268 induction also supports this conclusion. If refractory mechanisms had been recruited by chronic SW activity, the IEGP 
$s t g / s t g$
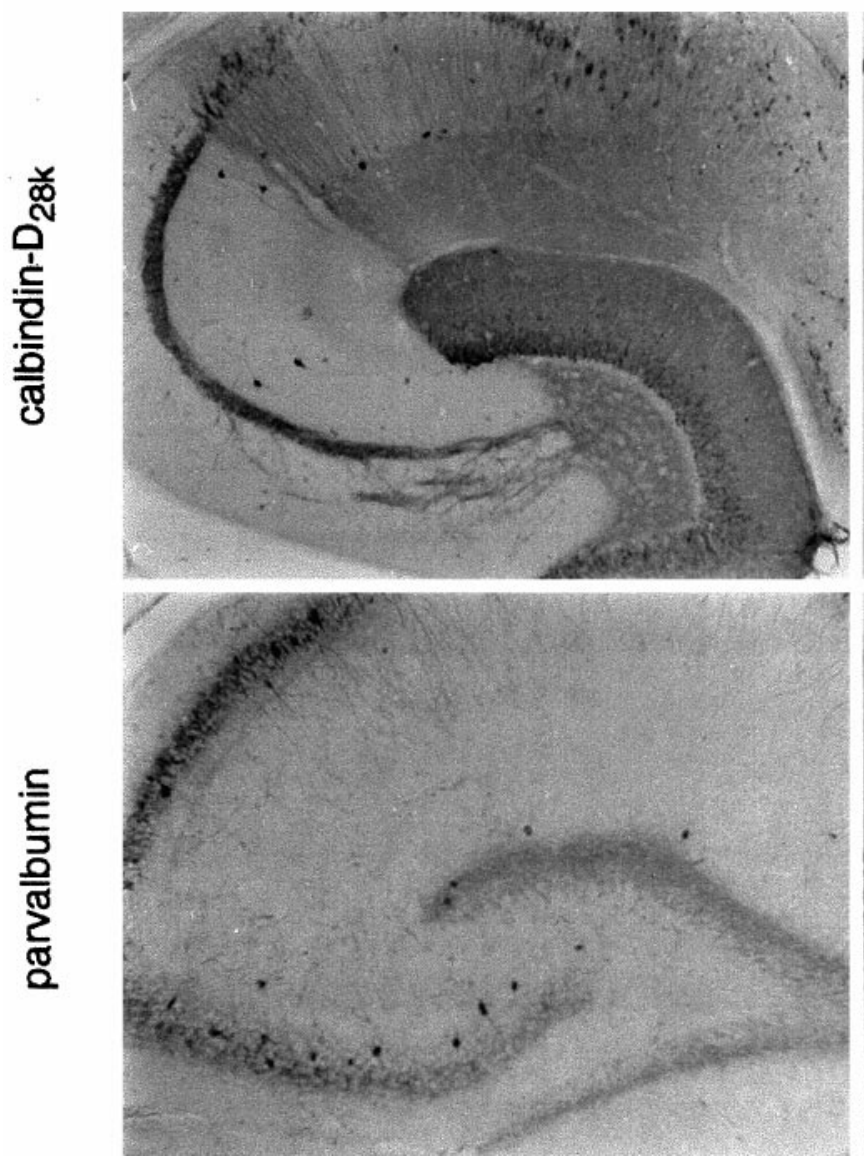

$+/+$
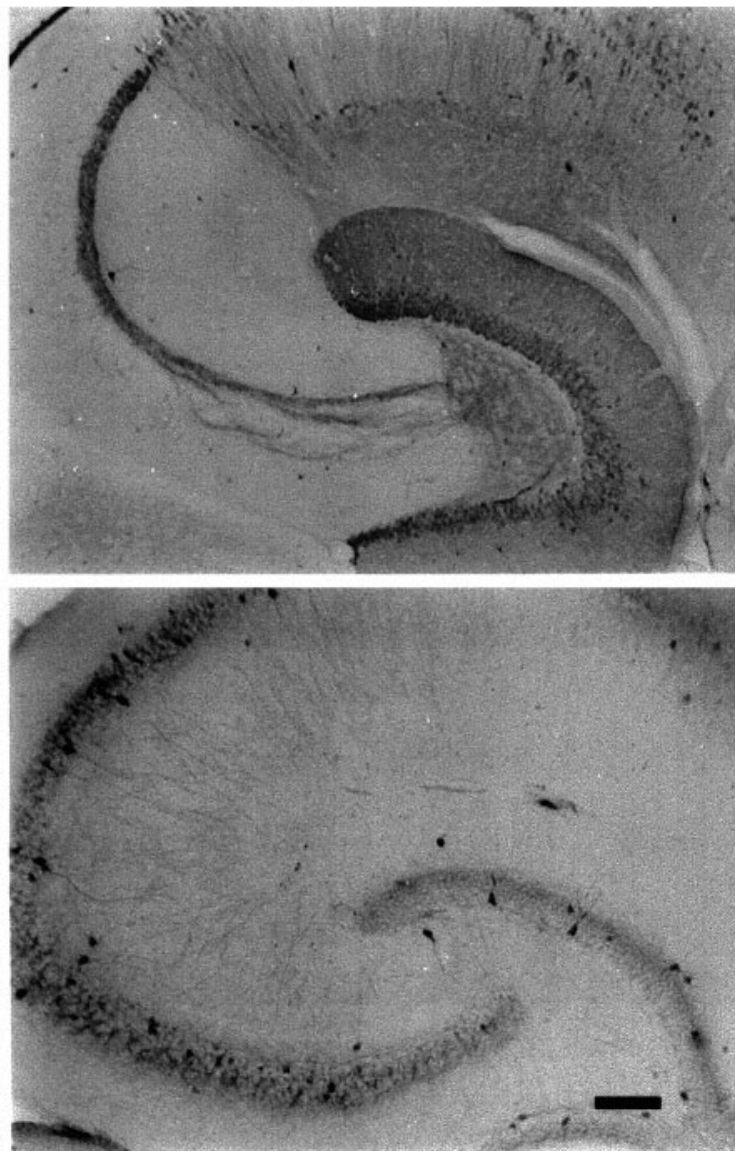

Figure 6. Inherited spike-wave seizures do not alter calcium-binding protein levels in the stargazer hippocampus. Comparison of calbindin- $\mathrm{D}_{28 \mathrm{k}}$ and parvalbumin immunohistochemistry in adult stg/stg and its wild-type control. No consistent differences in the staining patterns of these two calcium-binding proteins were detected between these two genotypes. Scale bar, $100 \mu \mathrm{m}$.

response after KA administration in $s t g / s t g$ mice would have been diminished relative to that in KA-treated $+/+$ mice.

$\mathrm{stg} / \mathrm{stg}$ neurons show no increases in the $\mathrm{Ca}^{2+}$-buffering proteins calbindin- $D_{28 k}$ and parvalbumin

Several studies show that increases in intracellular $\mathrm{Ca}^{2+}$ are required for depolarization or seizure-induced expression of IEGs (Morgan and Curran, 1986; Lerea and McNamara, 1993). Intracellular calcium may be modulated in cells by the EF-hand (Persechini et al., 1989) calcium-binding proteins (CaBPs), such as calbindin- $\mathrm{D}_{28 \mathrm{k}}$ and parvalbumin (Morrissey et al., 1978; Baimbridge et al., 1982; Celio, 1986; Kohr et al., 1991). The levels of these proteins within the hippocampal formation correlate with vulnerability to excitotoxic induced cell death or neurodegeneration (Sloviter, 1989; Hof et al., 1991; Mattson et al., 1991; Sloviter et al., 1991) and can be changed by activity-dependent processes, including seizures (Miller and Baimbridge, 1983; Kamphuis et al., 1989; Lowenstein et al., 1991).

To determine whether SW seizures might regulate the level of cytoplasmic CaBPs, with potential secondary effects on transynaptic IEGP expression, the patterns of calbindin- $\mathrm{D}_{28 \mathrm{k}}$ and parvalbumin IHC in stg/stg brains were compared with those in $+/+$ mice. Adult stg/stg mutants displayed normal hippocampal patterns of calbindin- $\mathrm{D}_{28 \mathrm{k}}$ and parvalbumin expression relative to the $+/+$ mice (Fig. 6). In both genotypes, calbindin- $\mathrm{D}_{28 \mathrm{k}}$ was expressed in DG and CA1, but not CA3 pyramidal cells. The dentate granule cell MF projections to $\mathrm{CA} 3$, and the dendritic layer (stratum oriens) of CA1 showed marked calbindin- $\mathrm{D}_{28 \mathrm{k}}$ expression. No genotypic differences were observed in other brain regions. Parvalbumin expression differed from the pattern seen with calbindin- $\mathrm{D}_{28 \mathrm{k}}$ antibody. Parvalbumin was expressed in a fiber plexus surrounding dentate granule cells and hippocampal pyramidal cells. Most parvalbumin staining was found in interneurons of the DG (stratum granulosum) and pyramidal cell layer (stratum pyramidale), but was also not altered in the mutant hippocampus. In both genotypes, scattered parvalbumin staining neurons were found in the neocortex, thalamic relay nuclei, and the thalamic reticular nucleus. In addition, strong staining was observed in the cerebellar cortex, particularly in the Purkinje cell layer. No genotypic differences in the pattern of parvalbumin expression were observed. These data provide no evidence for the seizure-induced changes in calbindin- $\mathrm{D}_{28 \mathrm{k}}$ or parvalbumin seen in convulsive seizure models that could alter intracellular $\mathrm{Ca}^{2+}$ buffering or IEGP induction.

\section{DISCUSSION}

The absence of elevated IEGP expression in $s t g / s t g$ hippocampus before and during the period of MF sprouting demonstrates that 
specific increases in c-Fos, c-Jun, and Zif/268 seen in convulsive models of epilepsy are not obligatory signals for hippocampal MF reorganization. The failure of SW synchronization to elicit cellular IEGP responses in the stargazer absence epilepsy model is apparently not prevented by stimulus-transcription coupling defects in hippocampal neurons, subthreshold seizure activation, intracellular refractory mechanisms, or abnormal levels of the $\mathrm{Ca}^{2+}$-buffering proteins calbindin- $\mathrm{D}_{28 \mathrm{k}}$ and parvalbumin. These findings demonstrate that alternative gene transcription pathways for triggering MF sprouting must exist. In addition, because the synchronization patterns of SW and tonic-clonic seizures differentially regulate IEGP expression, our data suggest that these two seizure types are associated with marked differences in neuronal depolarization and calcium influx and give rise to fundamentally distinct patterns of downstream molecular signaling.

\section{c-Fos, c-Jun, and Zif/268 increases are not obligatory for MF reorganization}

Elevations of IEG expression correlate well with pathological sprouting of nerve axons at several sites in the nervous system (Bao et al., 1993; Herdegen et al., 1993; Kenney and Kocsis, 1998), and the induction of $c$-fos, $c$-jun, and zif/268 have been specifically correlated with MF sprouting (Sutula et al., 1988; Popovici et al., 1990; Simonato, 1993; Kiessling and Gass, 1993; Watanabe et al., 1996; Represa and Ben-Ari, 1997). Although these models are accompanied by early or delayed cell death, stargazer mutants display an identical pattern of MF recurrent sprouting with little evidence of neuronal cell loss except at very late stages (Qiao and Noebels, 1993). The presence of sprouting in the absence of elevations of c-Fos, c-Jun, and Zif/268 in the mutant demonstrate that these IEGPs are not obligatory in hippocampal synaptic reorganization and that other regulators of downstream neuronal gene expression induce this pattern of reactive axonal plasticity.

In a test of this hypothesis, Watanabe et al. (1996) reported that a null mutant of $c$-fos showed impaired development of kindling and reduced MF sprouting and concluded that there was a functional role for $c$-fos in triggering new axon collateral growth in granule cells. However, these authors could not exclude maturational alterations in the $c$-fos $-/-$ mutant brain preceding the kindling experiment that might diminish both processes, and the specific contribution of c-Fos in activating neuronal growthrelated genes after seizures in the limbic system remained untested. Some kindling-induced sprouting was still observed in $c$-fos $-/-$ mice, and it was suggested that alternative transcription factor pathways might compensate for the absence of $c$-fos. In contrast to the $c$-fos null mutation, a related study of zif/268 (NGFI-A) null mutants concluded that zif/268 did not play a required role in the expression of $\mathrm{MF}$ sprouting (Zheng et al., 1998). In the stargazer model, unlike the null mutations, the IEGPs c-Fos, c-Jun, and Zif/268 are available throughout brain development. Our findings specifically demonstrate that they are not induced before or during sprouting and, therefore, play a nonobligate role.

Along with our evidence that they are not necessary for reactive sprouting, c-Fos protein increases are also not sufficient to initiate reactive plasticity, because not all models with pathological c-Fos expression in granule cells show MF sprouting. Although KA induction uniformly produced elevated granule cell c-Fos elevations (Le Gal La Salle, 1988; Popovici et al., 1988; Sonnenberg et al., 1989; Pennypacker et al., 1993), Cronin et al.
(1992) has shown that of 25 rats with KA-induced seizures only 17 displayed the dense MF sprouting response.

The elevation of c-Fos, c-Jun, Zif/268, and other IEGPs [e.g., JunD and the 35-37 kDa fos-related antigen (FRA)] (Bing et al., 1996, 1997; Feng et al., 1997) has been viewed as an attractive mechanism for inducing axonal growth because they are transcription factors that bind to activator protein-1 (AP-1) sites. AP-1 is a promoter element regulating a variety of genes reported to contribute to sprouting, such as growth-associated protein-43 (GAP-43) (Eggen et al., 1994; Bendotti et al., 1994, 1997) and nerve growth factor (NGF) (Adams et al., 1997). Murine overexpression of a GAP-43 transgene potentiates MF reorganization (Aigner et al., 1995), and null mutants of GAP-43 display axon pathfinding defects (Strittmater et al., 1995). Induction of neurotrophic factors like NGF, neurotrophin-3, brain-derived neurotrophic factor, and basic fibroblast growth factor (bFGF) have been associated with sprouting (Gall, 1993; Gall et al., 1994; Kar et al., 1997; Mathern et al., 1997), and blockade of the tyrosine kinase B receptor for growth factors abolishes induction of MF sprouting (Hughes et al., 1998). Anti-NGF IgGs and NGF domains that interfere with neurotrophin binding also inhibit kindling-induced sprouting (Rashid et al., 1995; Van der Zee et al., 1995), and the time course of increased neurotrophic activity after KA administration parallels MF reorganization (Lowenstein et al., 1993). Finally, other mechanisms regulating sprouting have been proposed that are not directly related to AP-1 activation in neurons. Represa and Ben-Ari (1997) suggest that MF terminal branches may sprout under the influence of local astrocytes that could favor axon growth by secreting neuronal cell adhesion molecule (Niquet et al., 1993) and trophic factors such as bFGF or by not secreting inhibitory substrate molecules such as tenascin-C (Niquet et al., 1995).

\section{Convulsive and nonconvulsive synchronization give rise to different patterns of stimulus-transcription coupling}

The finding that convulsive and SW synchronization display differential patterns of IEGP expression suggests that these two seizure types may produce distinct profiles of AP-1-binding complexes in the CNS. Because specific temporal patterns of AP-1induced genes can result in altered long-term plasticity, this pathway for gene regulation may contribute to the variations in neurite outgrowth, neuronal differentiation, and cell death found between convulsive and SW seizures.

Several lines of evidence indicate that prolonged IEGP elevations may be more closely related to cell death than seizureinduced neurite outgrowth; this hypothesis is compatible with the differences observed in IEGP expression between the models of convulsive and nonconvulsive epilepsy. $c$-fos expression can be an indicator of impending death in certain neurons in the developing and adult CNS (Gonzalez-Martin et al., 1992; Smeyne et al., 1993; Dragunow and Preston, 1995; Kasof et al., 1995; Goodenough et al., 1997). IEGP elevations are more prolonged after KA seizures, in which there is substantial cell death, than after PTZ seizures, in which there is not (Kasof et al., 1995). c-Jun is associated with cell death in the hippocampus after status epilepticus and ischemia (Dragunow et al., 1993). Certain classes of neurons have large increases in c-jun and undergo apoptosis when deprived of NGF. Ham et al. (1995) demonstrated that a c-Jun dominant negative mutation protected mouse sympathetic neurons from apoptotic cell death induced by NGF withdrawal, and showed that overexpression of c-Jun in sympathetic neurons in- 
duced apoptosis. KA-induced convulsive seizures are followed by marked regional induction of IEGPs in specific hippocampal pyramidal neurons, and these areas show the most severe loss of cells (Nadler et al., 1980a,b; Nitecka et al., 1984). Conversely, SW seizures in the stargazer model are associated with only a minor and late loss of hilar interneurons in the mutant hippocampus not seen until several months after the onset of the seizures (Qiao and Noebels, 1993).

\section{Alteration in IEGP expression between spike-wave and convulsive seizure patterns may depend on different levels of depolarization and calcium entry}

Why don't hypersynchronous spike-wave absence seizures induce IEGP expression? Since the discovery that $c$-fos mRNA transcripts rapidly rise after depolarization and influx of calcium in PC12 cells (Greenberg et al., 1986; Morgan and Curran, 1986), calcium has been linked as a required second messenger for $c$-fos induction (Morgan and Curran, 1991a), along with the activation of other regulatory elements (Robertson et al., 1995). Although the route by which calcium enters a neuron during a seizure may differ, the resulting transcription of $c$-fos still occurs (Lerea et al., 1992), and calcium entry during different patterns of stimulation may lead to distinct arrays of IEG expression. The fact that SW seizures in $s t g / s t g$ do not induce IEGPs, whereas KA-induced seizures produce robust responses, and the fact that $s t g / s t g$ and $+/+$ mice show equivalent levels and patterns of two CaBPs suggests that SW seizures cause (1) lower depolarizing levels, and (2) lesser degrees of $\mathrm{Ca}^{2+}$ influx in synchronized neurons than do convulsive seizures.

This tentative conclusion is supported by proposals (Gloor, 1979) that the SW discharge is a true "inhibitory" seizure, a pattern of generalized synchronous oscillations in neurons deficient in paroxysmal depolarization shifts (PDSs) and showing increased postsynaptic inhibition, as opposed to the seizures characteristic of convulsive epileptic syndromes. According to this hypothesis, the repatterning of cellular excitation during the brief "spike" of a SW seizure is not caused by excessive neuronal depolarization, and impulse activity does not exceed the normal range; the prolonged IPSPs $(>250 \mathrm{msec}$ ) corresponding to the inhibitory ECoG "wave" also predict substantially less neuronal depolarization throughout the duration of the seizure episode (Gloor, 1984; Giaretta et al., 1987). This proposed mechanism to account for the lack of IEGP expression during SW seizures has been generally confirmed during in vivo neocortical intracellular recordings in the SW epileptic rat that show only brief depolarizations without PDSs during SW seizures, and no decreases in extracellular $\mathrm{Ca}^{2+}$ levels determined by $\mathrm{Ca}^{2+}$-sensitive microelectrodes as seen during convulsive discharges (Heinemann et al., 1977; R. Pumain, personal communication). Initial in vivo studies in a rat SW model using two photon confocal microscopy also confirm the absence of increased intracellular free $\mathrm{Ca}^{2+}$ during SW patterns of synchronization (Buzsaki et al., 1997).

\section{REFERENCES}

Adams B, Sazgar M, Osehobo P, Van der Zee CE, Diamond J, Fahnestock M, Racine RJ (1997) Nerve growth factor accelerates seizure development, enhances mossy fiber sprouting, and attenuates seizureinduced decreases in neuronal density in the kindling model of epilepsy. J Neurosci 17:5288-5296.

Aigner L, Arber S, Kapfhammer JP, Laux T, Schneider C, Botteri F, Brenner HR, Caroni P (1995) Overexpression of the neural growthassociated protein GAP-43 induces nerve sprouting in the adult nervous system of transgenic mice. Cell 83:269-278.
Baimbridge KG, Miller JJ, Parkes CO (1982) Calcium-binding protein distribution in the rat brain. Brain Res 239:519-525.

Bao J, Reier PJ, Munson JB (1993) Enhancement of c-fos expression in neurons of the rat spinal cord after partial denervation: evidence for functional plasticity. Exp Neurol 122:189-195.

Bendotti C, Pende M, Samanin R (1994) Expression of GAP-43 in the granule cells of rat hippocampus after seizure-induced sprouting of mossy fibres: in situ hybridization and immunocytochemical studies. Eur J Neurosci 6:509-515.

Bendotti C, Baldessari S, Pende M, Southgate T, Guglielmetti F, Samanin R (1997) Relationship between GAP-43 expression in the dentate gyrus and synaptic reorganization of hippocampal mossy fibres in rats treated with kainic acid. Eur J Neurosci 9:93-101.

Bing G, McMillian M, Kim H, Pennypacker K, Feng Z, Qi Q, Kong LY, Iadarola M, Hong JS (1996) Long-term expression of the 35,000 mol. wt fos-related antigen in rat brain after kainic acid treatment. Neuroscience 73:1159-1174.

Bing G, Wilson B, Hudson P, Jin L, Feng Z, Zhang W, Bing R, Hong JS (1997) A single dose of kainic acid elevates the levels of enkephalins and activator protein-1 transcription factors in the hippocampus for up to 1 year. Proc Natl Acad Sci USA 94:9422-9427.

Buzsaki G, Svoboda K, Denk W, Tank DW (1997) In vivo calcium dynamics in neocortical pyramidal neurons during high voltage spindles studied with intracellular recordings and 2-photon laser scanning microscopy. Soc Neurosci Abstr 23:1006.

Cavazos JE, Sutula TP (1990) Progressive neuronal loss induced by kindling: a possible mechanism for mossy fiber synaptic reorganization and hippocampal sclerosis. Brain Res 527:1-6.

Cavazos JE, Golarai G, Sutula TP (1991) Mossy fiber synaptic reorganization induced by kindling: time course of development, progression, and permanence. J Neurosci 11:2795-2803.

Celio MR (1986) Parvalbumin in most $\gamma$-aminobutyric acid-containing neurons of the rat cerebral cortex. Science 231:995-997.

Chafetz RS, Nahm WK, Noebels JL (1995) Aberrant expression of neuropeptide $\mathrm{Y}$ in hippocampal mossy fibers in the absence of local cell injury following the onset of spike-wave synchronization. Brain Res Mol Brain Res 31:111-121.

Chen Z-L, Yoshida S, Kato K, Momota Y, Suzuki J, Tanaka T, Ito J, Nishino H, Aimoto S, Kiyama H, Shiosaka S (1995) Expression and activity-dependent changes of a novel limbic-serine protease gene in the hippocampus. J Neurosci 15:5088-5097.

Cotman CW, Nieto-Sampedro M, Harris EW (1981) Synapse replacement in the nervous system of adult vertebrates. Physiol Rev 61:684-784.

Cronin J, Obenaus A, Houser CR, Dudek FE (1992) Electrophysiology of dentate granule cells after kainate-induced synaptic reorganization of the mossy fibers. Brain Res 573:305-310.

Curran T, Morgan JI (1995) Fos: an immediate-early transcription factor in neurons. J. Neurobiol 26:403-412.

Darian-Smith C, Gilbert CD (1994) Axonal sprouting accompanies functional reorganization in adult cat striate cortex. Nature 368:737-740.

Dragunow M, Faull RLM (1990) MK-801 induces c-fos protein in thalamic and neocortical neurons of rat brain. Neurosci Lett 111:39-45.

Dragunow M, Preston K (1995) The role of inducible transcription factors in apoptotic nerve cell death. Brain Res Brain Res Rev 21:1-28.

Dragunow M, Robertson HA (1987) Generalized seizures induce c-fos protein(s) in mammalian neurons. Neurosci Lett 82:157-161.

Dragunow M, Young D, Hughes P, MacGibbon G, Lawlor P, Singleton K, Sirimanne E, Beilharz E, Gluckman P (1993) Is c-Jun involved in nerve cell death following status epilepticus and hypoxic-ischaemic brain injury? Brain Res Mol Brain Res 18:347-352.

Eggen BJ, Nielander HB, Rensen-de-Leeuw MG, Schotman P, Gispen WH, Schrama LH (1994) Identification of two promotor regions in the rat B-50/GAP-43 gene. Brain Res Mol Brain Res 23:221-234.

Ennulat DJ, Babb SM, Cohen BM (1994) Persistent reduction of immediate early gene mRNA in rat forebrain following single or multiple doses of cocaine. Brain Res Mol Brain Res 26:106-112.

Feng Z, Zhang W, Hudson P, Bing G, Feng W, Hong JS (1997) Characterization of the long-lasting activator protein-1 complex induced by kainic acid treatment. Brain Res 770:53-59.

Fitzgerald M, Woolf CJ, Shortland P (1990) Collateral sprouting of the central terminals of cutaneous primary afferent neurons in the rat spinal cord: pattern, morphology, and influence of targets. J Comp Neurol 300:370-385. 
Gall CM (1993) Seizure-induced changes in neurotrophin expression: implications for epilepsy. Exp Neurol 124:150-166.

Gall CM, Isackson PJ (1989) Limbic seizures increase neuronal production of messenger RNA for nerve growth factor. Science 245:758-761.

Gall CM, Berschauer R, Isackson PJ (1994) Seizure increase basic fibroblast growth factor mRNA in adult rat forebrain neurons and glia. Brain Res Mol Brain Res 21:190-205.

Giaretta D, Avoli M, Gloor P (1987) Intracellular recordings in pericruciate neurons during spike and wave discharges of feline generalized penicillin epilepsy. Brain Res 405:68-79.

Gloor P (1979) Generalized epilepsy with spike-and-wave discharge: a reinterpretation of its electrographic and clinical manifestations. Epilepsia 20:571-588.

Gloor P (1984) Electrophysiology of generalized epilepsy. In: Electrophysiology of epilepsy (Schwartzkroin PA, Wheal HV, eds), pp 107136. London: Academic.

Golarai G, Cavazos JE, Sutula TP (1992) Activation of the dentate gyrus by pentylentetrazol evoked seizures induces mossy fiber synaptic reorganization. Brain Res 593:257-264.

Gonzalez-Martin C, de Diego I, Crespo D, Fairen A (1992) Transient c-fos expression accompanies naturally occurring cell death in the developing interhemispheric cortex of the rat. Brain Res Dev Brain Res 68:83-95.

Goodenough S, Davidson M, Chen W, Beckmann A, Pujic Z, Otsuki M, Matsumoto I, Wilce P (1997) Immediate early gene expression and delayed cell death in limbic areas of the rat brain after kainic acid treatment and recovery in the cold. Exp Neurol 145:451-461.

Greenberg ME, Ziff EB, Greene LA (1986) Stimulation of neuronal acetylcholine receptors induces rapid gene transcription. Science 234:80-83.

Ham J, Babij C, Whitfield J, Pfarr CM, Lallemand D, Yaniv M, Rubin LL (1995) A c-Jun dominant negative mutant protects sympathetic neurons against programmed cell death. Neuron 14:927-939.

Heinemann U, Lux HD, Gutnick MJ (1977) Extracellular free calcium and potassium during paroxysmal activity in the cerebral cortex of the cat. Exp Brain Res 27:237-243.

Heller AH, Dichter MA, Sidman RL (1983) Anticonvulsant sensitivity of absence seizures in the Tottering mutant mouse. Epilepsia 24:25-34.

Herdegen T, Bastmeyer M, Bahr M, Stuermer C, Bravo R, Zimmermann M (1993) Expression of JUN, KROX, and CREB transcription factors in goldfish and rat retinal ganglion cells following optic nerve lesion is related to axonal sprouting. J Neurobiol 24:528-543.

Hof PR, Cox K, Young WG, Celio MR, Rogers J, Morrison JH (1991) Parvalbumin-immunoreactive neurons in the neocortex are resistant to degeneration in Alzheimer's disease. J Neuropathol Exp Neurol 50:451-462.

Houser CR, Miyashiro JE, Swartz BE, Walsh GO, Rich JR, DelgadoEscueta AV (1990) Altered patterns of dynorphin immunoreactivity suggest mossy fiber reorganization in human hippocampal epilepsy. J Neurosci 10:267-282.

Hsu SM, Raine L, Fanger H (1981) Use of avidin-biotin-peroxidase complex $(\mathrm{ABC})$ in immunoperoxidase techniques: a comparison between ABC and unlabeled antibody (PAP) procedures. J Histochem Cytochem 29:577-580.

Hughes P, Dragunow M, Beilharz E, Lawlor P, Gluckman P (1993) MK801 induces immediate-early gene proteins and BDNF mRNA in rat cerebrocortical neurones. NeuroReport 4:183-186.

Hughes PE, Young D, Preston KM, Yan Q, Dragunow M (1998) Differential regulation by MK801 of immediate-early genes, brain-derived neurotrophic factor and trk receptor mRNA induced by a kindling after-discharge. Brain Res Mol Brain Res 53:138-151.

Jensen FE, Firkusny IR, Mower GD (1993) Differences in c-fos immunoreactivity due to age and mode of seizure induction. Brain Res Mol Brain Res 17:185-193.

Kamphuis W, Huisman E, Wadman WJ, Heizmann CW, Lopes da Silva FH (1989) Kindling induced changes in parvalbumin immunoreactivity in rat hippocampus and its relation to long-term decrease in GABAimmunoreactivity. Brain Res 479:23-34.

Kar S, Seto D, Dore S, Chabot JG, Quirion R (1997) Systemic administration of kainic acid induces selective time dependent decreased in [125I]insulin-like growth factor I, [125I]insulin-like growth factor II and [125I]insulin receptor binding sites in adult rat hippocampal formation. Neuroscience 80:1041-1055.

Kasof GM, Mandelzys A, Maika SD, Hammer RE, Curran T, Morgan JI (1995) Kainic acid-induced neuronal death is associated with DNA damage and a unique immediate-early gene response in c-fos-lac Z transgenic rats. J Neurosci 15:4238-4249.

Kenney AM, Kocsis JD (1998) Peripheral axotomy induces long-term c-Jun amino-terminal kinase-1 activation and activator protein-1 binding activity by c-Jun and junD in adult rat dorsal root ganglia in vivo. J Neurosci 18:1318-1328.

Kiessling M, Gass P (1993) Immediate early gene expression in experimental epilepsy. Brain Pathol 3:381-393.

Kohr G, Lambert CE, Mody I (1991) Calbindin-D ${ }_{28 \mathrm{~K}}$ (CaBP) levels and calcium currents in acutely dissociated epileptic neurons. Exp Brain Res 85:543-551.

Konopka D, Nowicka D, Filipkowski RK, Kaczmarek L (1995) Kainateevoked secondary gene expression in the rat hippocampus. Neurosci Lett 185:167-170.

Le Gal La Salle G (1988) Long-lasting and sequential increase of c-fos oncoprotein expression in kainic acid-induced status epilepticus. Neurosci Lett 88:127-130.

Lerea LS, McNamara JO (1993) Ionotropic glutamate receptor subtypes activate c-fos transcription by distinct calcium-requiring intracellular signaling pathways. Neuron 10:31-41.

Lerea LS, Butler LS, McNamara JO (1992) NMDA and non-NMDA receptor-mediated increase of c-fos mRNA in dentate gyrus neurons involves calcium influx via different routes. J Neurosci 12:2973-2981.

Lowenstein DH, Miles MF, Hatam F, McCabe T (1991) Up regulation of calbindin-D28K mRNA in the rat hippocampus following focal stimulation of the perforant path. Neuron 6:627-633.

Lowenstein DH, Seren MS, Longo FM (1993) Prolonged increases in neurotrophic activity associated with kainate-induced hippocampal synaptic reorganization. Neuroscience 56:597-604.

Marescaux C, Vergnes M, Depaulis A (1992) Genetic absence epilepsy in rats from Strasbourg-A review. J Neural Transm [Suppl] 35:37-69.

Mathern GW, Babb TL, Micevych PE, Blanco CE, Pretorius JK (1997) Granule cell mRNA levels for BDNF, NGF, and NT-3 correlate with neuron losses or supragranular mossy fiber sprouting in the chronically damaged and epileptic human hippocampus. Mol Chem Neuropathol 30:53-76.

Mattson MP, Rychlik B, Chu C, Christakos S (1991) Evidence for calcium-reducing and excito-protective roles for the calcium-binding protein calbindin- $\mathrm{D}_{28 \mathrm{k}}$ in cultured hippocampal neurons. Neuron 6:41-51.

Miller JJ, Baimbridge KG (1983) Biochemical and immunohistochemical correlates of kindling-induced epilepsy: role of calcium binding protein. Brain Res 278:322-326.

Morgan JI, Curran T (1986) Role of ion flux in the control of c-fos expression. Nature 322:552-555.

Morgan JI, Curran T (1991a) Stimulus-transcription coupling in the nervous system: involvement of the inducible proto-oncogenes fos and jun. Annu Rev Neurosci 14:421-451.

Morgan JI, Curran T (1991b) Proto-oncogene transcription factors and epilepsy. Trends Pharmacol Sci 12:343-349.

Morgan JI, Cohen DR, Hempstead JL, Curran T (1987) Mapping patterns of $c$-fos expression in the central nervous system after seizure. Science 237:192-197.

Morrissey RL, Empson RN, Zolock DT, Bikle DD, Bucci TJ (1978) Intestinal response to $1 \alpha, 25$-dihydroxycholecalciferol II. A timed study of the intracellular localization of calcium binding protein. Biochim Biophys Acta 538:34-41.

Nadler JV, Perry BW, Cotman CW (1980a) Selective reinnervation of hippocampal area CA1 and the fascia dentata after destruction of CA3-CA4 afferents with kainic acid. Brain Res 182:1-9.

Nadler JV, Perry BW, Gentry C, Cotman CW (1980b) Loss and reacquisition of hippocampal synapses after selective destruction of CA3CA4 afferents with kainic acid. Brain Res 191:387-403.

Nahm WK, Noebels JL (1995) NMDA receptor blockers paradoxically increase spike-wave synchronization and neocortical excitability in a mutant mouse model of spike-wave epilepsy, stargazer. Soc Neurosci Abstr 21:1965.

Nakao SI, Arai T, Mori K, Yasuhara O, Tooyama I, Kimura H (1993) High-dose ketamine does not induce c-Fos protein expression in rat hippocampus. Neurosci Lett 151:33-36.

Nedivi E, Hevroni D, Naot D, Israeli D, Citri Y (1993) Numerous candidate plasticity-related genes revealed by differential cDNA cloning. Nature 363:718-722.

Niquet J, Jorquera I, Ben-Ari Y, Represa A (1993) NCAM immunore- 
activity on mossy fibers and reactive astrocytes in the hippocampus of epileptic rats. Brain Res 626:106-116.

Niquet J, Jorquera I, Faissner A, Ben-Ari Y, Represa A (1995) Gliosis and axonal sprouting in the hippocampus of epileptic rats are associated with an increase of tenascin-C immunoreactivity. J Neurocytol 24:611-624.

Nitecka L, Tremblay E, Charton G, Bouillot JP, Berger ML, Ben-Ari Y (1984) Maturation of kainic acid seizure-brain damage syndrome in the rat. II. Histopathological sequelae. Neuroscience 13:1073-1094.

Noebels JL, Qiao X, Bronson RT, Spencer C, Davisson MT (1990) Stargazer: a new neurological mutant on chromosome 15 in the mouse with prolonged cortical seizures. Epilepsy Res 7:129-135.

Pennypacker KR, Walczak D, Thai L, Fannin R, Mason E, Douglass J, Hong JS (1993) Kainate-induced changes in opioid peptide genes and AP-1 protein expression in the rat hippocampus. $J$ Neurochem 60:204-211.

Persechini A, Moncrief ND, Kretsinger RH (1989) The EF-hand family of calcium-modulated proteins. Trends Neurosci 12:462-467.

Popovici T, Represa A, Crepel V, Barbin G, Beaudoin M, Ben-Ari Y (1990) Effects of kainic acid-induced seizures and ischemia on c-foslike proteins in rat brain. Brain Res 536:183-194.

Qiao X, Noebels JL (1993) Developmental analysis of hippocampal mossy fiber outgrowth in a mutant mouse with inherited spike-wave seizures. J Neurosci 13:4622-4635.

Racine RJ (1972) Modification of seizure activity by electrical stimulation: II. motor seizure. Electroencephalogr Clin Neurophysiol 32:281-294.

Rashid K, Van der Zee CE, Ross GM, Chapman CA, Stanisz J, Riopelle RJ, Racine RJ, Fahnestock M (1995) A nerve growth factor peptide retards seizure development and inhibits neuronal sprouting in a rat model of epilepsy. Proc Natl Acad Sci USA 92:9495-9499.

Represa A, Ben-Ari Y (1997) Molecular and cellular cascades in seizure-induced neosynapse formation. Adv Neurol 72:25-34.

Robertson LM, Kerppola TK, Vendrell M, Luk D, Smeyne RJ, Bocchiaro C, Morgan JI, Curran T (1995) Regulation of c-fos expression in transgenic mice requires multiple interdependent transcription control elements. Neuron 14:241-252.

Schreiber SS, Tocco G, Najm I, Finch CE, Johnson SA, Baudry M (1992) Absence of c-fos induction in neonatal rat brain after seizures. Neurosci Lett 136:31-35.

Sharp JW, Sagar SM, Sharp FR (1990) MK801 induces the $70 \mathrm{kD}$ heat shock protein and Fos in the cingulate gyrus. Soc Neurosci Abstr 16:1122.

Sheng M, Greenberg ME (1990) The regulation and function of $c$-fos and other immediate early genes in the nervous system. Neuron 4:477-485.

Simonato M (1993) A pathogenetic hypothesis of temporal lobe epilepsy. Pharmacol Res 27:217-225.

Sloviter RS (1989) Calcium-binding protein (calbindin- $\mathrm{D}_{28 \mathrm{k}}$ ) and parv- albumin immunocytochemistry: localization in the rat hippocampus with specific reference to the selective vulnerability of hippocampal neurons to seizure activity. J Comp Neurol 280:183-196.

Sloviter RS, Sollas AL, Barbaro NM, Laxer KD (1991) Calcium-binding protein (calbindin-D28K) and parvalbumin immunocytochemistry in the normal and epileptic human hippocampus. J Comp Neurol 308:381-396.

Smeyne RJ, Vendrell M, Hayward M, Baker SJ, Miao GG, Schilling K, Robertson LM, Curran T, Morgan JI (1993) Continuous c-fos expression precedes programmed cell death in vivo. Nature 363:166-169.

Sonnenberg JL, Mitchelmore C, Macgregor-Leon PF, Hempstead J, Morgan JI, Curran T (1989) Glutamate receptor agonists increase the expression of Fos, Fra and AP-1 DNA binding activity in the mammalian brain. J Neurosci Res 24:72-80.

Stanfield BB (1989) Excessive intra- and supragranular mossy fibers in the dentate gyrus of tottering ( $\mathrm{tg} / \mathrm{tg}$ ) mice. Brain Res 480:294-299.

Strittmatter SM, Fankhauser C, Huang PL, Mashimo H, Fishman MC (1995) Neuronal pathfinding is abnormal in mice lacking the neuronal growth cone protein GAP-43. Cell 80:445-452.

Sutula T, He X-X, Cavazos J, Scott G (1988) Synaptic reorganization in the hippocampus induced by abnormal functional activity. Science 239:1147-1150.

Tauck DL, Nadler JV (1985) Evidence of functional mossy fiber sprouting in hippocampal formation of kainic-acid treated rats. J Neurosci 5:1016-1022.

Van der Zee, Rashid K, Le K, Moore KA, Stanisz J, Diamond J, Racine RJ, Fahnestock M (1995) Intraventricular administration of antibodies to nerve growth factor retards kindling and blocks mossy fiber sprouting in adult rats. J Neurosci 15:5316-5323.

Wallace MN, Fredens K (1992) Activated astrocytes of the mouse hippocampus contain high levels of NADPH-diaphorase. NeuroReport 3:953-956.

Watanabe Y, Johnson RS, Butler LS, Binder DK, Spiegelman BM, Papaioannou VE, McNamara JO (1996) Null mutation of c-fos impairs structural and functional plasticities in the kindling model of epilepsy. J Neurosci 16:3827-3836.

West JR, Dewey SL (1984) Mossy fiber sprouting in the fascia dentata after unilateral entorhinal lesions: quantitative analysis using computer-assisted image processing. Neuroscience 13:377-384.

Willoughby JO, Mackenzie L, Hiscock. JJ, Sagar S (1993) Non convulsive spike-wave discharges do not induce Fos in cerebro-cortical neurons. Mol Brain Res 18:178-180.

Winston SM, Hayward MD, Nestler EJ, Duman RS (1990) Chronic electroconvulsive seizures down-regulate expression of the immediateearly genes c-fos and c-jun in rat cerebral cortex. J Neurochem 54:1920-1925.

Zheng D, Butler LS, McNamara JO (1998) Kindling and associated mossy fibre sprouting are not affected in mice deficient of NGFI-A/ NGFI-B genes. Neuroscience 83:251-258. 